\title{
H19-DMR allele-specific methylation analysis reveals epigenetic heterogeneity of CTCF binding site 6 but not of site 5 in head-and-neck carcinomas: A pilot case-control analysis
}

\author{
LEDA ISABEL DE CASTRO VALENTE ESTEVES ${ }^{1}$, NILVA DE KARLA CERVIGNE ${ }^{1}$, \\ AFONSO DO CARMO JAVARONI ${ }^{3}$, JOSÉ MAGRIN ${ }^{4}$, LUIZ PAULO KOWALSKI ${ }^{4}$, \\ CLÁUDIA APARECIDA RAINHO ${ }^{1}$ and SILVIA REGINA ROGATTO ${ }^{2}$
}

\author{
${ }^{1}$ Department of Genetics, Institute of Biosciences, ${ }^{2}$ Department of Urology, NeoGene Laboratory, \\ Faculty of Medicine, UNESP - Sao Paulo State University, Botucatu, SP 18618-000; ${ }^{3}$ Department of Head and \\ Neck Surgery, Amaral Carvalho Hospital, Jau, SP 17210-080; ${ }^{4}$ Department of Head and Neck Surgery and \\ Otorhinolaryngology, A.C. Camargo Hospital, Sao Paulo, SP 01509-010, Brazil
}

Received August 16, 2005; Accepted September 26, 2005

\begin{abstract}
Aberrant methylation of seven potential binding sites of the CTCF factor in the differentially methylated region upstream of the $\mathrm{H} 19$ gene (H19-DMR) has been suggested as critical for the regulation of IGF2 and H19 imprinted genes. In this study, we analyzed the allele-specific methylation pattern of CTCF binding sites 5 and 6 using methylationsensitive restriction enzyme PCR followed by RFLP analysis in matched tumoral and lymphocyte DNA from head-andneck squamous cell carcinoma (HNSCC) patients, as well as in lymphocyte DNA from control individuals who were cancerfree. The monoallelic methylation pattern was maintained in CTCF binding site 5 in 22 heterozygous out of 91 samples analyzed. Nevertheless, a biallelic methylation pattern was detected in CTCF binding site 6 in a subgroup of HNSCC patients as a somatic acquired feature of tumor cells. An atypical biallelic methylation was also observed in both tumor and lymphocyte DNA from two patients, and at a high frequency in the control group ( 29 out of 64 informative controls). Additionally, we found that the $\mathrm{C} / \mathrm{T}$ transition detected by Hha RFLP suppressed one dinucleotide $\mathrm{CpG}$ in critical CTCF binding site 6 , of a mutation showing polymorphic frequencies. Although a heterogeneous methylation pattern was observed after DNA sequencing modified by sodium bisulfite, the biallelic methylation pattern was confirmed in 9 out of 10 HNSCCs. These findings are likely to be relevant in the epigenetic regulation of the DMR, especially
\end{abstract}

Correspondence to: Dr Silvia Regina Rogatto, Department of Urology, NeoGene Laboratory, Faculty of Medicine, UNESP, Botucatu, SP 18618-000, Brazil

E-mail: rogatto@fmb.unesp.br

Key words: differentially methylated region, genomic imprinting, head-and-neck carcinomas, polymorphism, $H 19$ gene in pathological conditions in which the imprinting of $I G F 2$ and $\mathrm{H} 19$ genes is disrupted.

\section{Introduction}

Alterations in the genomic methylation patterns have been widely observed in human tumors. Global genomic hypomethylation (1), promoter hypermethylation of $\mathrm{CpG}$ islands $(2,3)$, and loss of imprinting (LOI) or loss of normal parental origin-dependent gene silencing are some of the epigenetic abnormalities found in human neoplasms (4).

In normal tissue, promoter $\mathrm{CpG}$ islands are usually unmethylated. However, imprinted genes are an exception, with one of the parental alleles being methylated. Imprinted genes are specifically expressed from the maternal or paternal allele during mammalian development. Several imprinted genes have been identified, with $H 19$ and IGF2, located on chromosome $11 \mathrm{p} 15.5$, showing the strongest association with cancer. These two genes are closely linked and show mutually exclusive expression (5). H19 encodes an apparently untranslated, maternally expressed transcript and $I G F 2$ encodes the insulin-like growth factor 2, a paternally expressed fetal growth factor. The promoter region of $H 19$ is methylated only on the paternal allele, known as the differentially methylated region or H19-DMR. This region is a key domain in controlling the imprinting of this locus (6-8), since monoallelic expression of the $H 19$ and IGF2 genes depends on the hypomethylation of the maternal allele and hypermethylation of the paternal allele of the $H 19$ upstream region.

In tumors, DNA hypermethylation in the promoter region is associated with a marked down-regulation of $H 19$ gene expression and $I G F 2$ biallelic expression. This event was first identified in childhood tumors $(9,10)$. In Wilms' tumors, IGF2 LOI was associated with aberrant methylation of the normally unmethylated maternal allele at the DMR-H19 $(11,12)$. IGF2 LOI has also been reported in common adult malignancies, including ovarian (13), colon (14), lung (15), bladder $(16)$ and head and neck $(17,18)$ cancers. 
CTCF is an evolutionarily conserved zinc finger phosphoprotein (19). H19-DMR contains seven potential CTCF binding sites. These sites are located upstream of the transcriptional initiation site, and their methylation can act as an insulator by precluding CTCF binding in H19-DMR (20). In human tumors, the methylation analysis of H19-DMR has revealed clones in which the CTCF binding sites were methylated in both alleles, supporting a mechanism in which methylation eliminates the function of the DMR as a chromatin insulator and, thus, leads to biallelic IGF2 expression (21-23). Takay et al (21) evaluated the seven potential CTCF binding sites in H19-DMR and found that only the sixth binding site showed allele-specific methylation in normal human embryonic ureteral tissue. However, in Wilms' tumor (22), colorectal cancer (23), and bladder cancer (21), aberrant hypermethylation of the sixth CTCF binding site has been observed.

Recently, IGF2 gene LOI was reported in lymphocytes of $28 \%$ of individuals with a family history of colorectal cancer and in about $10 \%$ of healthy individuals (24). These findings suggested that LOI could be a valuable predictive marker of an individual risk for colorectal cancer (25). LOI of the IGF2 and $H 19$ genes has been reported for a subgroup of patients with head-and-neck squamous cell carcinomas (HNSCC) $(17,18)$. In the present study, we investigated the pattern of methylation in the H19-DMR of HNSCC compared with a matched cohort of cancer-free individuals. Such a comprehensive analysis of H19-DMR methylation has not been previously reported in HNSCC.

\section{Materials and methods}

Patients and controls. Ninety-five samples of HNSCC from different anatomical locations (60 from the oral cavity, 20 from the pharynx, and 15 from the larynx) were surgically removed from 15 women and 80 men (mean age, 57.4; ranging from 22 to 86 years old) attending the A.C. Camargo Hospital, São Paulo and the Amaral Carvalho Hospital, Jaú, São Paulo State, Brazil. A peripheral blood sample was also collected from all patients. Participating patients gave their informed consent for the study prior to sampling. This work was approved by the Brazilian National Ethics Committee (CONEP, protocol 942/2001).

None of the patients had undergone radiotherapy or chemotherapy before surgery. Each sample was submitted for histopathological evaluation to ensure a minimum of $80 \%$ tumor cellularity. The histopathological classification of the tumors was described according to the WHO International Classification of Diseases for Oncology (26). The clinical staging was determined using the TNM staging system (27).

Control lymphocytes were obtained from 157 individuals with a mean age of 44.8 , ranging from 16 to 87 years old, with no documented history of cancer. The control group had the same ethnic diversity observed in the Brazilian population as the HNSCC patient group.

DNA extraction. Genomic DNA from tumor tissue and corresponding blood lymphocyte was prepared by standard SDS/proteinase K digestion followed by phenol and chloroform extraction and ethanol precipitation.
Genomic polymorphisms for the screening of informative cases. The AvaI and HhaI polymorphisms were used to assess allele-specific methylation of the DMR. Initially, DNA from the peripheral blood of each patient was amplified by PCR (polymerase chain reaction). The primers used for the AvaI RFLP were PI (5'-GAGCCTGCCAAGCAGAGCG-3') (sense) and PIII (5'-CACATAAGTAGGCGTGACTTGA-3') (antisense). The reaction mixture contained dNTPs $(125 \mu \mathrm{M}$ each), primers (0.2 mM each), $1.5 \mathrm{mM} \mathrm{MgCl}_{2}, 10 \mathrm{mM}$ Tris$\mathrm{HCl}, \mathrm{pH} 8.3,50 \mathrm{mM} \mathrm{KCl}$, and $1 \mathrm{U}$ of Taq polymerase. The amplification conditions consisted of 35 cycles of $94^{\circ} \mathrm{C}$ for $1 \mathrm{~min}, 59^{\circ} \mathrm{C}$ for $45 \mathrm{sec}$ and $72^{\circ} \mathrm{C}$ for $2 \mathrm{~min}$. One microliter of this reaction mixture was used in a nested PCR with the primers PIa (5'-GTGTCCCCATTCTTTGGATG-3') (sense) and PIIIb (5'-GTTTCACACTAGGGCCGAGA-3') (antisense), in a $25 \mu \mathrm{l}$ reaction as described above. The amplification conditions consisted of 35 cycles of $94^{\circ} \mathrm{C}$ for $1 \mathrm{~min}, 57^{\circ} \mathrm{C}$ for $1 \mathrm{~min}$ and $72^{\circ} \mathrm{C}$ for $1 \mathrm{~min}$. The amplified fragment was then precipitated with ethanol, air-dried, and digested with $15 \mathrm{U}$ of AvaI.

The Hha polymorphism was analyzed after PCR amplification using the primers PII (5'-CAATGAGGTGTC CCAGTTCCA-3') (sense) and PIII (5'-CACATAAGTAGGC GTGACTTGA-3') (antisense). The conditions consisted of 35 cycles of $94^{\circ} \mathrm{C}$ for $1 \mathrm{~min}, 59^{\circ} \mathrm{C}$ for $1 \mathrm{~min}$, and $72^{\circ} \mathrm{C}$ for $1 \mathrm{~min}$. One microliter of the PCR product was used in a nested PCR with the primers PIIa (5'-CCTAGTGTGAAA CCCTTCTCG-3') (sense) and PIIIb (5'-TGTGGATAATG CCCGACCTGA-3') (antisense), and the same reaction conditions as described above. The amplified product was digested with $15 \mathrm{U}$ of HhaI.

After cleavage with the endonucleases AvaI or HhaI, the PCR products were submitted to electrophoresis on $2 \%$ agarose gels followed by staining with ethidium bromide. Informative heterozygous cases were analyzed further to detect allelespecific methylation.

Allelic analysis of methylation. Matched normal and tumor DNA samples heterozygous for the AvaI or HhaI RFLP were used in a methylation-sensitive restriction enzyme PCR (MSRE-PCR) in which $2 \mu \mathrm{g}$ of genomic DNA was completely digested with $150 \mathrm{U}$ of $\mathrm{HpaII}$ or $\mathrm{MspI}$ endonuclease at $37^{\circ} \mathrm{C}$ overnight. Phenol/chloroform was used to inactivate the enzymes. The digested DNA was precipitated with ethanol, air-dried and resuspended in $20 \mu 1$ of sterile water. To determine the allele-specificity of methylation, $2 \mu 1$ of digested DNA was amplified by PCR and the AvaI and HhaI RFLPs were analyzed as described above. Using this approach, a differential methylation pattern is seen as a mutually exclusive amplification of each allele.

Bisulfite treatment and allele-specific methylation analysis. The conversion of DNA by bisulfite was performed using an established protocol (28), with modifications. The bisulfite reactions were performed using $2 \mu \mathrm{g}$ of genomic DNA. Denatured DNA (treated with $0.2 \mathrm{M} \mathrm{NaOH}$ at $37^{\circ} \mathrm{C}$ for $10 \mathrm{~min}$ ) was incubated with freshly prepared $3 \mathrm{M}$ sodium bisulfite/ $10 \mathrm{mM}$ hydroquinone, $\mathrm{pH} 5.0$, in a total volume of $580 \mu 1$, at $50^{\circ} \mathrm{C}$ for $16 \mathrm{~h}$, under mineral oil. The DNA was purified using the kit Wizard DNA Clean-UP System (Promega), 
followed by neutralization with $28 \mu 1$ of $5 \mathrm{M}$ ammonium acetate (pH 7.0). Ten micrograms of glycogen (Invitrogen Life Technologies) and $300 \mu 1$ of ethanol were then added to precipitate the DNA. $\mathrm{NaOH}$ was subsequently added to a final concentration of $0.3 \mathrm{M}$ at room temperature for $10 \mathrm{~min}$. The bisulfite-modified DNA was resuspended in $30 \mu 1$ of $10 \mathrm{mM}$ Tris- $\mathrm{HCl} / 0.1 \mathrm{mM}$ EDTA, $\mathrm{pH} 7.5$, and stored at $-20^{\circ} \mathrm{C}$.

Eighteen CpGs located at -2226 to -2003 bp upstream of the $H 19$ start site were amplified by nested PCR using the primers Bis1 (5'-GTAGGGTTTTTGGTAGGTATAGAGT-3') (sense) and Bis2 (5'-CACTAAAAAAACAATTATCAAT TC-3') (antisense) for the first reaction and Bis3 (5'-GTA TAGTATATGGGTATTTTTGGAGG-3') (sense) and Bis4 (5'-TAAATATCCTATTCCCAAATAACCC-3') (antisense) for the second reaction. PCR was performed in a $25 \mu 1$ reaction volume containing $0.25 \mu \mathrm{M}$ of each primer, $200 \mu \mathrm{M}$ of each dNTP, $20 \mathrm{mM}$ Tris-HCl, pH 8.4, $50 \mathrm{mM} \mathrm{KCl}, 1.5 \mathrm{mM}$ $\mathrm{MgCl}_{2}$, and $1 \mathrm{U}$ of Taq polymerase. The PCR conditions consisted of 35 cycles of $95^{\circ} \mathrm{C}$ for $1 \mathrm{~min}, 53^{\circ} \mathrm{C}$ for the first PCR and $48^{\circ} \mathrm{C}$ for the second PCR for $1 \mathrm{~min}$, and $72^{\circ} \mathrm{C}$ for $2 \mathrm{~min}$. The amplified fragment was visualized after electrophoresis on $1 \%$ agarose gels. The specific band was then purified using the QIAquick gel extraction kit (Qiagen) and cloned in a TA vector (TOPO TA Cloning ${ }^{\circledR}$ kit for sequencing, Invitrogen - Life Technologies). DNA sequencing was performed in an ABI PRISM Big Dye Terminator Cycle Sequencing Ready Reaction kit, according to the manufacturer's instructions. The sequencing reactions were run in an ABI 377 DNA sequencer (Applied Biosystems).

Phred/Phrap software was used to evaluate the quality of the data (29-31). Only sequences with a minimum score of 15 in each base at the critical CTCF binding site were used to evaluate the methylation pattern. The software MethTools (32) was used to generate an annotated map of the methylation profile for each individual assay.

To distinguish the alleles, we used a SNP as a reference (-2088 bp upstream of the H19 transcription start site). When the case was non-informative for this SNP, the maternal and paternal alleles were inferred by the methylation pattern (21).

\section{Results}

Genomic polymorphisms for screening of informative cases and allele-specific methylation analysis. To investigate whether there is abnormal methylation in the H19-DMR of HNSCC patients, we modified a protocol based on methylation-sensitive restriction enzyme PCR and posterior RFLP analysis, which permits allele differentiation (33). Using an AvaI RFLP, 91/95 cases were genotyped and 22 heterozygous informative cases were detected. We assessed the methylation status of three CpGs located at positions $-2633,-2574$, and -2496 , close to CTCF binding site 5. In these heterozygous samples (tumor matched with normal DNA from the same patient), a mutually exclusive amplification of each allele (absence or presence of the AvaI site) was observed after cleavage of the DNA with an excess of HpaII in all samples. These findings were compatible with the monoallelic methylation of these three CpG dinucleotides in the DMR of the paternal allele (Fig. 1A and $\mathrm{B})$.
A second RFLP analysis revealed that 43 patients were heterozygous for the HhaI polymorphism. Using this RFLP, it was possible to evaluate the methylation pattern of two CpGs located at positions -2237 and -2062 that flanked the sixth CTCF binding site. Of the 43 cases which were informative for this polymorphism, there was correspondence between the methylation pattern in tumor and normal lymphocyte DNA from the same patient in 33 samples, indicating that the constitutional lymphocyte methylation pattern was unaltered in HNSCC DNA. In eight samples, a monoallelic methylation pattern was observed in control DNA and a biallelic methylation pattern in tumor DNA, demonstrating the acquisition of abnormal methylation in HNSCC. However, in two patients, biallelic methylation at these two $\mathrm{CpG}$ sites was detected in normal and tumoral DNA (cases 4 and 10) (Fig. 1C and Table I).

Biallelic methylation and the monoallelic patterns were compared to clinical parameters. A significant association was found between biallelic methylation and patients $>57$ years old at the time of diagnosis ( $\mathrm{p}=0.034$, Fisher's exact test) (Table II).

The methylation pattern of the CTCF binding site is polymorphic. Based on the hypermethylation detected in DNA samples from peripheral blood in two cases, the allele-specific HhaI MSRE-PCR analysis was also conducted on 67 heterozygous individuals without cancer. Three samples did not amplify after the treatment with HpaII. To exclude falsepositive results caused by partial digestion, all of the tests were performed with an excess of HpaII enzyme and in duplicate. A monoallelic pattern of methylation was observed in 35 out of 64 samples. Hypermethylation was detected in 29 DNA samples. These data indicated that the methylation status of the CpG dinucleotides at positions -2237 and -2062 was polymorphic.

Sequencing of sodium bisulfite modified DNA. To confirm the biallelic methylation pattern found in 10 cases of HNSCC detected using the MSRE-PCR approach described above, a 250-bp fragment from DMR that contained CTCF binding site 6 was sequenced. Using this assay, it was possible to assess the methylation status of each $\mathrm{CpG}$ and the methylation pattern of the $18 \mathrm{CpG}$ contained in this region.

The A/C polymorphism at position -2088 was used to distinguish the parental origin of the alleles. The methylation level of CpG -2062 (one of the two CpG sites evaluated by the MSRE-PCR assay) confirmed biallelic methylation in 9 out of 10 informative cases. In 2 of these 9 tumors (cases 38 and 44), at least one allele of each parental origin was completely methylated. Considering total methylation content (73\%) and biallelic methylation found on sequencing, sample 38 was considered hypermethylated, although case 44 showed a total methylation content of $52.1 \%$ and biallelic methylation. Cases 9, 10, 16, 19, 27, 43 and 46 ranged in their total methylation content from $11.1 \%$ to $36.8 \%$ and were considered hypomethylated (data not shown).

An intriguing observation was that an abnormal methylation pattern was detected in the lymphocytes of one patient (case 4) who had alleles that were completely methylated in the CTCF binding site from different parental origins and presented a total methylation content of $70 \%$ (Fig. 1D). The 


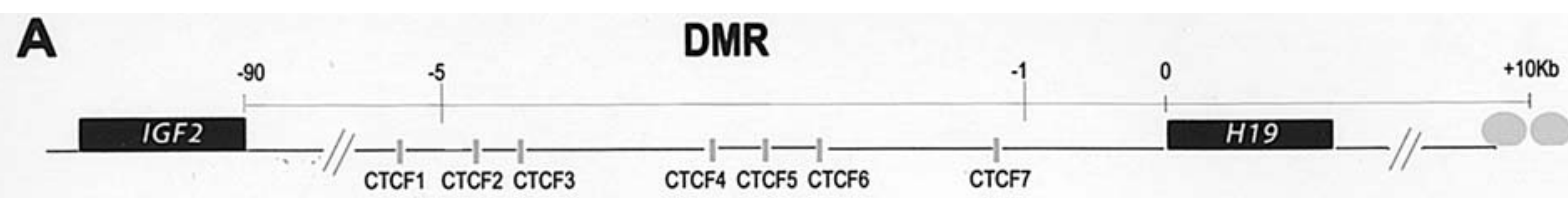

B

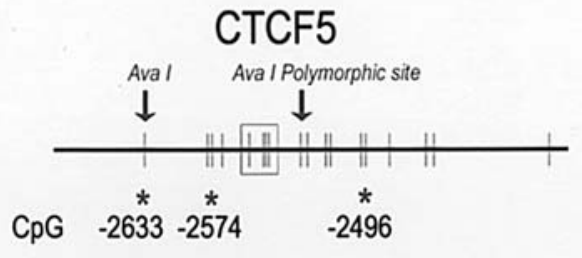

Before Hpall treatment

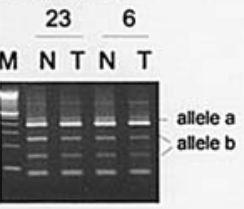

After Hpall treatment

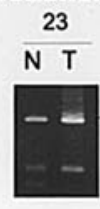

\section{6}

N T

allele a

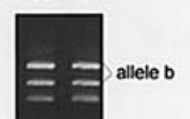

D

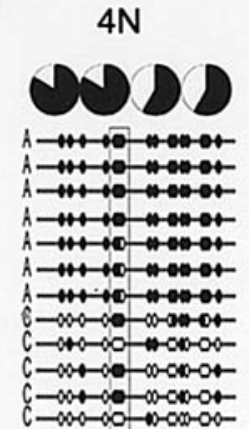

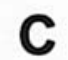

C

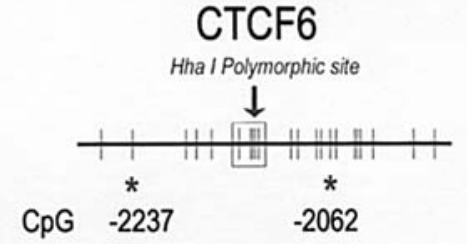

Before Hpall treatment

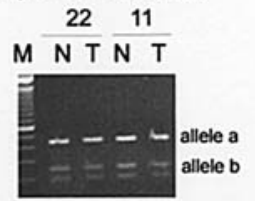

After Hpall treatment

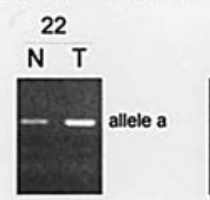

11

N T
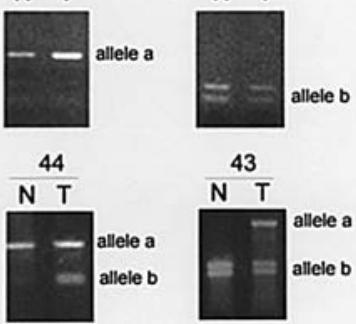

43

N T

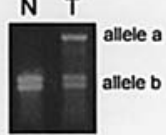

$\mathrm{N}^{4} \mathrm{~T}$

10

N T

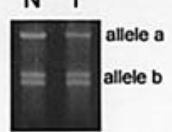

Figure 1. Analysis of the methylation pattern of CTCF binding sites 5 and 6 by the methyl-sensitive restriction endonuclease assay (MSRE-PCR). (A) Physical map of IGF2-H19 locus. Upstream of the H19 gene, the seven potential CTCF binding sites are shown in the DMR. The ellipses downstream of the $\mathrm{H} 19$ gene indicate(s) the enhancers. (B) Allelic-specific methylation analysis of the CTCF5 binding site by RFLP AvaI. HpaII restriction sites are indicated at positions $-2633,-2574$, and $-2496(*)$. Representative AvaI heterozygous cases with monoallelic methylation patterns are shown before and after HpaII digestion (cases 6 and 23). (C) Allele-specific methylation analysis of the CTCF6 binding site by RFLP HhaI. CpG at positions -2237 and -2062 are coincident with HpaII sites $(*)$, which flanked this site. A monoallelic methylation pattern was found in cases 11 and 22 in the peripheral blood and in the tumoral DNA. Biallelic methylation was detected as a somatic acquired feature by tumor cells in cases 43 and 44 . Cases 4 and 10 showed biallelic methylation patterns as a constitutional characteristic. M, molecular weight marker 100 bp DNA ladder; N, normal DNA from peripheral leukocytes; T, tumoral DNA. (D) Distribution of unmethylated and methylated $\mathrm{CpG}$ (open and closed circle, respectively) in the CTFC6 binding site. Methylation pattern observed in tumoral and peripheral leukocytes DNA from case 4. Each pie graph summarizes the methylation content of each CpG dinucleotide at positions $-2135,-2133$, -213 , and -2128 in the critical CTCF6 binding site after sequencing of bisulfite-treated DNA. Black segments indicate methylcytosine percentage and white segments indicate unmethylated cytosine percentage. Each line represents a single DNA template molecule. A polymorphism was used to distinguish the parental origin of the alleles.

tumor sample from this patient also showed alleles that were completely methylated in the CTCF binding site from different parental origins, although the total methylation content was normal $(51.3 \%)$.
The HhaI polymorphism is a C/T transition in CTCF binding site 6 in H19-DMR. RFLP-PCR and sequencing analysis of the PCR product after CTCF binding site 6 region cloning showed that the RFLP HhaI, used only as a marker to 
Table I. Clinical and histopathological data and the $5^{\text {th }}$ and $6^{\text {th }}$ CTCF binding site's methylation patterns in informative heterozygous HNSCC.

\begin{tabular}{|c|c|c|c|c|c|c|c|c|c|c|c|c|c|c|}
\hline Cases & Age & Sex & Site & $\mathrm{T}$ & $\mathrm{N}$ & M & Recurrence & Metastasis & $\begin{array}{l}\text { Follow-up } \\
\quad(\mathrm{m})\end{array}$ & Status $^{\mathrm{a}}$ & $\begin{array}{l}\text { HhaI } \\
\text { geno- } \\
\text { typing }\end{array}$ & $\begin{array}{c}\text { CTCF } \\
\text { binding site } 6 \\
\text { methylation }\end{array}$ & $\begin{array}{l}\text { AvaI } \\
\text { geno- } \\
\text { typing }\end{array}$ & $\begin{array}{c}\text { CTCF } \\
\text { binding site } 5 \\
\text { methylation }\end{array}$ \\
\hline 1 & 62 & M & Tongue & 4 & 1 & 0 & - & $\begin{array}{c}\text { Cervical lymph node, } \\
\text { pyriform sinus }\end{array}$ & 4 & 3 & $\mathrm{~b} / \mathrm{b}$ & NI & $\mathrm{a} / \mathrm{b}$ & Monoallelic \\
\hline 2 & 54 & M & Tongue & 4 & $2 \mathrm{c}$ & 0 & - & - & 9 & 1 & $\mathrm{a} / \mathrm{b}$ & Monoallelic & $\mathrm{b} / \mathrm{b}$ & NI \\
\hline 3 & 66 & M & Tongue & 4 & $2 \mathrm{c}$ & 0 & - & - & 3 & 5 & $\mathrm{a} / \mathrm{b}$ & Monoallelic & $\mathrm{b} / \mathrm{b}$ & NI \\
\hline 4 & 72 & M & Tongue & 4 & 1 & 0 & - & - & 45 & 1 & $\mathrm{a} / \mathrm{b}$ & Biallelic & $\mathrm{a} / \mathrm{b}$ & Monoallelic \\
\hline 5 & 67 & M & Tongue & 4 & 0 & 0 & - & - & 25 & 5 & $\mathrm{a} / \mathrm{b}$ & Monoallelic & $\mathrm{a} / \mathrm{b}$ & Monoallelic \\
\hline 6 & 61 & M & Tongue & 4 & 0 & 0 & - & Bone and lung & 9 & 3 & $\mathrm{a} / \mathrm{b}$ & Monoallelic & $\mathrm{a} / \mathrm{b}$ & Monoallelic \\
\hline 7 & 57 & M & Tongue & 3 & $2 \mathrm{a}$ & 0 & - & - & 9 & 4 & $\mathrm{a} / \mathrm{b}$ & Monoallelic & $\mathrm{b} / \mathrm{b}$ & NI \\
\hline 8 & 56 & $\mathrm{M}$ & Tongue & 3 & 1 & 0 & - & - & 51 & 4 & $\mathrm{a} / \mathrm{b}$ & Monoallelic & $\mathrm{a} / \mathrm{b}$ & Monoallelic \\
\hline 9 & 48 & M & Tongue & 3 & 1 & 0 & Regional & - & 3 & 3 & $\mathrm{a} / \mathrm{b}$ & Biallelic & $\mathrm{b} / \mathrm{b}$ & NI \\
\hline 10 & 86 & $\mathrm{~F}$ & Tongue & 3 & 1 & 0 & - & - & 6 & 4 & $\mathrm{a} / \mathrm{b}$ & Biallelic & $\mathrm{b} / \mathrm{b}$ & NI \\
\hline 11 & 50 & M & Tongue & 3 & 0 & 0 & - & - & 16 & 4 & $\mathrm{a} / \mathrm{b}$ & Monoallelic & $\mathrm{b} / \mathrm{b}$ & NI \\
\hline 12 & 68 & $\mathrm{~F}$ & Tongue & 3 & 0 & 0 & Local & - & 37 & 3 & $\mathrm{a} / \mathrm{b}$ & Monoallelic & $a / b$ & Monoallelic \\
\hline 13 & 43 & M & Tongue & 2 & 1 & 1 & Loco regional & Lymph node & 20 & 2 & $\mathrm{a} / \mathrm{b}$ & Monoallelic & $\mathrm{b} / \mathrm{b}$ & NI \\
\hline 14 & 56 & $\mathrm{M}$ & Tongue & 2 & 1 & 0 & - & Bone and lung & 38 & 3 & $\mathrm{a} / \mathrm{b}$ & Monoallelic & $\mathrm{b} / \mathrm{b}$ & NI \\
\hline 15 & 46 & $\mathrm{~F}$ & Tongue & 2 & 1 & 0 & - & Bone & 14 & 3 & $\mathrm{a} / \mathrm{b}$ & Monoallelic & $\mathrm{b} / \mathrm{b}$ & NI \\
\hline 16 & 39 & M & Tongue & 2 & 0 & 0 & - & - & 37 & 1 & $\mathrm{a} / \mathrm{b}$ & Biallelic & $a / b$ & Monoallelic \\
\hline 17 & 51 & M & Tongue & 2 & 1 & 0 & - & - & 47 & 1 & $\mathrm{a} / \mathrm{b}$ & Monoallelic & $\mathrm{b} / \mathrm{b}$ & NI \\
\hline 18 & 33 & M & Tongue & 1 & 0 & 0 & - & - & 63 & 1 & $\mathrm{a} / \mathrm{b}$ & Monoallelic & $\mathrm{b} / \mathrm{b}$ & NI \\
\hline 19 & 73 & $\mathrm{~F}$ & Tongue & $\mathrm{X}$ & $\mathrm{x}$ & 0 & - & - & 52 & 1 & $\mathrm{a} / \mathrm{b}$ & Biallelic & $\mathrm{b} / \mathrm{b}$ & NI \\
\hline 20 & 71 & M & Lower gum & 4 & 1 & 0 & Regional & Lung & 17 & 5 & $\mathrm{a} / \mathrm{a}$ & NI & $\mathrm{a} / \mathrm{b}$ & Monoallelic \\
\hline 21 & 61 & $\mathrm{M}$ & Gum & 4 & 0 & 0 & - & - & 77 & 1 & $\mathrm{a} / \mathrm{b}$ & Monoallelic & $\mathrm{b} / \mathrm{b}$ & NI \\
\hline 22 & 55 & $\mathrm{~F}$ & Gum & 2 & 1 & 0 & - & - & 40 & 1 & $\mathrm{a} / \mathrm{b}$ & Monoallelic & $\mathrm{b} / \mathrm{b}$ & NI \\
\hline 23 & 57 & M & Floor of mouth & 4 & $2 b$ & 0 & - & - & 50 & 1 & $\mathrm{a} / \mathrm{b}$ & Monoallelic & $\mathrm{a} / \mathrm{b}$ & Monoallelic \\
\hline 24 & 53 & M & Floor of mouth & 3 & 0 & 0 & - & - & 228 & 1 & $\mathrm{a} / \mathrm{b}$ & Monoallelic & $\mathrm{b} / \mathrm{b}$ & NI \\
\hline 25 & 50 & M & Floor of mouth & 3 & 0 & 0 & Regional & - & 11 & 3 & $\mathrm{a} / \mathrm{b}$ & Monoallelic & $\mathrm{a} / \mathrm{b}$ & Monoallelic \\
\hline 26 & 57 & M & Floor of mouth & 3 & 0 & 0 & - & - & 70 & 1 & $\mathrm{~b} / \mathrm{b}$ & NI & $\mathrm{a} / \mathrm{b}$ & Monoallelic \\
\hline 27 & 60 & $\mathrm{M}$ & Floor of mouth & 3 & 0 & 0 & Cervical & - & 12 & 5 & $\mathrm{a} / \mathrm{b}$ & Biallelic & $\mathrm{b} / \mathrm{b}$ & NI \\
\hline 28 & 49 & M & Floor of mouth & 2 & 0 & 0 & - & - & 47 & 5 & $\mathrm{a} / \mathrm{b}$ & Monoallelic & $\mathrm{b} / \mathrm{b}$ & NI \\
\hline 29 & 40 & M & Floor of mouth & 1 & 2 & 0 & Local & - & 5 & 3 & $\mathrm{a} / \mathrm{b}$ & Monoallelic & $\mathrm{b} / \mathrm{b}$ & NI \\
\hline 30 & 48 & $\mathrm{~F}$ & Floor of mouth & 1 & 0 & 0 & - & - & 33 & 1 & $\mathrm{~b} / \mathrm{b}$ & NI & $\mathrm{a} / \mathrm{b}$ & Monoallelic \\
\hline 31 & 69 & M & Retromolar & 4 & 3 & 0 & Regional & - & 11 & 3 & $\mathrm{a} / \mathrm{b}$ & Monoallelic & $\mathrm{b} / \mathrm{b}$ & NI \\
\hline 32 & 47 & $\mathrm{M}$ & Retromolar & 3 & 1 & 0 & - & - & 74 & 1 & $\mathrm{a} / \mathrm{b}$ & Monoallelic & $\mathrm{a} / \mathrm{b}$ & Monoallelic \\
\hline 33 & 71 & M & Retromolar & 3 & 1 & 0 & - & - & 71 & 1 & $\mathrm{a} / \mathrm{b}$ & Monoallelic & $\mathrm{b} / \mathrm{b}$ & NI \\
\hline 34 & 61 & $\mathrm{M}$ & Retromolar & 3 & 1 & 0 & Local & Mouth & 27 & 4 & $\mathrm{~b} / \mathrm{b}$ & NI & $\mathrm{a} / \mathrm{b}$ & Monoallelic \\
\hline 35 & 70 & M & Tonsil & 2 & 1 & 0 & Regional & - & 38 & 2 & $\mathrm{a} / \mathrm{b}$ & Monoallelic & $\mathrm{b} / \mathrm{b}$ & NI \\
\hline 36 & 55 & $\mathrm{M}$ & Tonsil & 2 & 0 & 0 & Loco regional & - & 86 & 3 & $\mathrm{a} / \mathrm{b}$ & Monoallelic & $\mathrm{b} / \mathrm{b}$ & NI \\
\hline 37 & 63 & M & Tonsil & 2 & 0 & 0 & - & - & 81 & 1 & $\mathrm{~b} / \mathrm{b}$ & NI & $a / b$ & Monoallelic \\
\hline 38 & 68 & M & Tonsil & 1 & 0 & 0 & Neck & - & 9 & 5 & $\mathrm{a} / \mathrm{b}$ & Biallelic & $\mathrm{b} / \mathrm{b}$ & NI \\
\hline 39 & 48 & M & Vallecula & 2 & $2 \mathrm{c}$ & 0 & - & - & 71 & 1 & $\mathrm{a} / \mathrm{b}$ & Monoallelic & $\mathrm{b} / \mathrm{b}$ & NI \\
\hline 40 & 48 & M & Vallecula & 2 & 0 & 0 & - & - & 80 & 1 & $\mathrm{a} / \mathrm{b}$ & Monoallelic & $\mathrm{b} / \mathrm{b}$ & NI \\
\hline 41 & 57 & M & Pyriform sinus & 3 & 1 & 0 & Esophagus & Cervical lymph nodes & 8 & 3 & $\mathrm{~b} / \mathrm{b}$ & NI & $\mathrm{a} / \mathrm{b}$ & Monoallelic \\
\hline 42 & 61 & M & Pyriform sinus & 3 & 1 & 0 & - & Cervical lymph nodes & 14 & 2 & $\mathrm{a} / \mathrm{b}$ & Monoallelic & $\mathrm{Nd}$ & $\mathrm{Nd}$ \\
\hline 43 & 42 & M & Pyriform sinus & 3 & 1 & 0 & - & - & 33 & 1 & $\mathrm{a} / \mathrm{b}$ & Biallelic & $\mathrm{a} / \mathrm{b}$ & Monoallelic \\
\hline 44 & 58 & $\mathrm{M}$ & Pyriform sinus & 2 & 0 & 0 & Local & - & 28 & 3 & $\mathrm{a} / \mathrm{b}$ & Biallelic & $\mathrm{b} / \mathrm{b}$ & NI \\
\hline 45 & 57 & M & Supraglottis & 4 & 0 & 0 & - & Cervical lymph nodes & 27 & 5 & $\mathrm{a} / \mathrm{b}$ & Monoallelic & $\mathrm{a} / \mathrm{b}$ & Monoallelic \\
\hline 46 & 76 & $\mathrm{~F}$ & Glottis & $2 b$ & 0 & 0 & Local & - & 26 & 2 & $\mathrm{a} / \mathrm{b}$ & Biallelic & $\mathrm{Nd}$ & $\mathrm{Nd}$ \\
\hline 47 & 47 & M & Glottis & 2 & 0 & 0 & - & - & 32 & 1 & $\mathrm{a} / \mathrm{b}$ & Monoallelic & $\mathrm{b} / \mathrm{b}$ & NI \\
\hline 48 & 49 & M & Glottis & 2 & 0 & 0 & - & - & 39 & 1 & $\mathrm{a} / \mathrm{b}$ & Monoallelic & $a / b$ & Monoallelic \\
\hline 49 & 70 & M & Epiglottis & $4 a$ & 0 & 0 & $\begin{array}{l}\text { Cervical, thyroid } \\
\text { cartilage }\end{array}$ & $\begin{array}{l}\text { Skin of the face, } \\
\text { pyriform sinus, } \\
\text { cervical lymph nodes }\end{array}$ & 27 & 3 & $\mathrm{~b} / \mathrm{b}$ & NI & $\mathrm{a} / \mathrm{b}$ & Monoallelic \\
\hline 50 & 43 & M & Epiglottis & 2 & 0 & 0 & - & - & 50 & 3 & $\mathrm{a} / \mathrm{b}$ & Monoallelic & $\mathrm{b} / \mathrm{b}$ & NI \\
\hline 51 & 63 & M & Larynx & 3 & 2 & 0 & Local & - & 7 & 4 & $\mathrm{~b} / \mathrm{b}$ & NI & $\mathrm{a} / \mathrm{b}$ & Monoallelic \\
\hline 52 & 61 & M & $\begin{array}{l}\text { Cervical } \\
\text { metastasis }\end{array}$ & $\mathrm{X}$ & $2 \mathrm{a}$ & 0 & $\begin{array}{l}\text { Primary, meta } \\
\text { unknown }\end{array}$ & Cervical & 66 & 2 & $\mathrm{a} / \mathrm{b}$ & Monoallelic & $a / b$ & Monoallelic \\
\hline
\end{tabular}

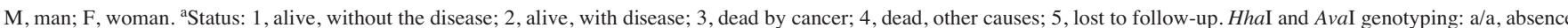
of the restriction enzyme site in both alleles; b/b, presence of restriction enzyme site in both alleles; a/b, heterozygous; NI, non-informative; Nd, not determined. 
Table II. H19 gene methylation status according to demographic and clinical variables.

\begin{tabular}{|c|c|c|c|}
\hline \multirow[b]{2}{*}{ Variable } & \multicolumn{3}{|c|}{ H19 gene methylation } \\
\hline & $\begin{array}{l}\text { Monoallelic methylation } \\
\mathrm{N}(\%)\end{array}$ & $\begin{array}{c}\text { Biallelic methylation } \\
\mathrm{N}(\%)\end{array}$ & $\mathrm{p}$-value ${ }^{\mathrm{a}}$ \\
\hline \multicolumn{4}{|l|}{ Age } \\
\hline$\leq 57$ & $23(53)$ & $3(7)$ & $0.034^{\mathrm{b}}$ \\
\hline$>57$ & $10(23)$ & $7(16)$ & \\
\hline \multicolumn{4}{|l|}{ Gender } \\
\hline Female & 3 (7) & $3(7)$ & 0.127 \\
\hline Male & $30(70)$ & $7(16)$ & \\
\hline \multicolumn{4}{|l|}{ Site } \\
\hline Oral cavity & 23 & 6 & $0.962^{\mathrm{c}}$ \\
\hline Oropharynx & 5 & 3 & \\
\hline Larynx & 5 & 1 & \\
\hline \multicolumn{4}{|l|}{ T stage } \\
\hline I-II & $16(37)$ & $5(12)$ & ND \\
\hline III-IV & $17(40)$ & $5(12)$ & \\
\hline \multicolumn{4}{|l|}{$\mathrm{N}$ stage } \\
\hline No & $15(35)$ & $6(14)$ & 0.488 \\
\hline $\mathrm{N}+$ & $18(42)$ & 4 (9) & \\
\hline \multicolumn{4}{|l|}{ Recurrence } \\
\hline No & $24(56)$ & $5(12)$ & 0.252 \\
\hline Yes & $9(21)$ & $5(12)$ & \\
\hline \multicolumn{4}{|l|}{ Metastasis } \\
\hline No & $25(58)$ & $9(21)$ & 0.659 \\
\hline Yes & $8(19)$ & 1 (2) & \\
\hline
\end{tabular}

${ }^{a} \mathrm{p}$-value obtained by Fisher's exact test with 5\% of significance level. ${ }^{b}$ Statistically significant. ${ }^{c} p$-value obtained by Chi-square test of independence.

differentiate the alleles, was located at critical CTCF binding site 6. DNA sequencing of heterozygous volunteers without cancer showed that this polymorphism was a $\mathrm{C} / \mathrm{T}$ transition at position -2133, and corresponded to the second of the four $\mathrm{CpG}$ dinucleotides inside the critical binding region of the CTCF protein. We used PCR-RFLP analysis in 157 control lymphocyte DNA samples to determine whether this polymorphism could be associated with a risk of developing HNSCC.

The presence of the restriction site, $H h a \mathrm{I}$, corresponds to allele $\mathrm{C}$ and the transition, $\mathrm{C} \rightarrow \mathrm{T}$, suppresses this site. The genotypes, CC, CT, and TT, for CTCF binding site 6 in the DMR did not differ between the patients with cancer $(26.3 \%$, $45.3 \%$, and $28.4 \%$, respectively) and the control group (38.2\%, $42.7 \%$, and $19.1 \%$, respectively). A comparison between the genotypes, $\mathrm{CC}$ and $\mathrm{CT}+\mathrm{TT}$, revealed a trend towards a lower frequency of the CC genotype in the HNSCC group $(p=0.0557$, Fisher's exact test). There were no significant differences in the frequencies of the $\mathrm{C}$ and $\mathrm{T}$ alleles between the HNSCC patients and control individuals. The overall calculated allele frequencies from the HNSCC patients and the control group were submitted to the NCBI database of SNPs (http://www.ncbi.nlm.nih.gov/SNP) (accession number, ss16341431; Ref, SNP rs 10732516).

\section{Discussion}

Tumor suppressor gene inactivation is one of the key early events of carcinogenesis. DNA-cytosine methylation in $\mathrm{CpG}$ islands of promoter regions is considered to be an important epigenetic mechanism contributing to tumor suppressor gene repression during tumor progression. A probable mechanism of imprinting loss in the IGF2/H19 domain, is the failure of appropriate CTCF binding due to disruption of the methylation pattern in the DMR (23).

Since H19-DMR is critical for the control of IGF2 and $H 19$ gene imprinting, the methylation status of this region was evaluated using a methyl-sensitive restriction endonuclease approach. There was a correlation between the methylation pattern in cancer cells and normal lymphocytes in 67\% (33/43) of the cases analyzed with the RFLP $H h a \mathrm{I}$ and in $100 \%$ of the cases analyzed with the RFLP AvaI. In these cases, there was $100 \%$ correspondence between the monoallelic parentalspecific methylation pattern in tumor and normal DNA from the same patient. The observation of mutually exclusive methylation from only one allele is in agreement with models specifying the parental-origin of the inheritable methylation pattern.

The detected methylation pattern of the three $\mathrm{CpG}$ dinucleotides close to CTCF binding site 5 was monoallelic in all samples of matched tumor and normal DNA. These results support the hypothesis that the removal of CTCF binding site 5 does not affect $H 19$ and IGF2 imprinting, indicating that this site is not critical for the coordinated regulation of these genes (8).

H19-DMR hypermethylation was detected in 10 out of 43 HNSCC (23\%) tumors. This finding confirmed that the methylation pattern was distorted in a subgroup of HNSCC patients. Furthermore, in 2 out of 10 cases, a comparative analysis between tumoral and peripheral blood lymphocyte DNA showed that there was also biallelic methylation in the peripheral blood. Deviations from the normal pattern of imprinting in $11 \mathrm{p} 15.5$ have been described in $>20$ different tumor types (34), which initially suggested that this abnormality was a somatic, tumor-specific event. LOI has been reported in pediatric and adult cancers, including HNSCC $(17,18)$, and is associated with disease progression in chronic myelogenous leukemia (35). LOI may precede the development of cancer and may serve as a marker for risk assessment since constitutional LOI has been reported in skin fibroblasts, normal kidney tissue, and peripheral blood leukocytes obtained from patients with Beckwith-Wiedemann syndrome, which predisposes individuals to pediatric tumors, such as Wilms' tumor and rhabdomyosarcoma $(36,37)$. Cui et al (14) reported LOI of the IGF2 gene in sporadic colorectal cancer and in matched normal colonic mucosa and leukocytes. Based on these data, LOI was suggested to be crucial for defining a subgroup of patients with cancer or individuals at risk of developing cancer. Recently, the same group (24) described the adjusted odds ratio for IGF2 LOI in lymphocytes as 5.15 for patients with a positive family history for colorectal cancer, 3.46 for patients with a personal history of colon adenomas and 21.7 for patients with colorectal cancer. This data indicated that IGF2 LOI could be a potential marker of the individual risk for developing colorectal cancer. The hypothesis that 
epigenetic changes affect cancer risk is supported by the model in which imprinting loss of Igf 2 alters the intestinal maturation of non-neoplastic tissue and tumorigenesis in mice (38).

An alternative hypothesis to explain our findings would be the occurrence of epigenetic alterations as a polymorphic characteristic in the population. Previous studies have shown that the functional imprinting of the IGF2 and $H 19$ genes is heterogeneous and polymorphic in blood cells from normal individuals $(39,40)$. More recently, Sandovici et al (41) observed a familial clustering of individuals with abnormal methylation ratios at $H 19-\mathrm{DMR}$ and reported that this trait was stable over nearly two decades. The authors concluded that, in approximately $6.5 \%$ of the population, $>10 \%$ of peripheral blood lymphocytes are methylated at $\mathrm{CpG}$ sites on the maternal allele. Together, these findings suggest the existence of inter-individual heterogeneity in the mono/ biallelic expression and methylation pattern of imprinted genes in the general population (42). To evaluate this hypothesis, we recruited 157 cancer-free control volunteers of both sexes and different ages. Sixty-seven heterozygous individuals were detected. The methylation analysis in this subgroup revealed the presence of biallelic methylation in 16 samples from women and in 13 from men, thus confirming the heterogeneity in the methylation pattern in H19-DMR. Our findings support the hypothesis that changes in the methylation pattern do not necessarily reflect the imprinting, unless they are also accompanied by parental allele-specific transcription (43).

MSRE-PCR is a low-resolution assay because of its ability to analyze only one or a few $\mathrm{CpG}$ dinucleotides in a given region. In our series, the CpGs at positions -2237 and -2062 bp flanking the sixth CTCF binding site and at positions -2633, -2574 , and -2496 near CTCF binding site 5 were successfully analyzed. This method provides a reproducible quantitative assessment of the ratio of methylation between the two parental alleles derived from an extensive sampling of representative genomic DNA. In contrast, sequencing of bisulfite-treated DNA surveys only a limited subset of $\mathrm{CpG}$ sites at a much lower molar equivalent (41).

The biallelic methylation detected by MSRE-PCR in 10 HNSCC samples and in the peripheral blood from one patient was confirmed by sequencing. Although completely methylated alleles of different parental origins were present in only a minority of the clones analyzed, a biallelic methylation pattern was detected in 9 out of 10 cases. These findings indicated that the intra-tumoral heterogeneity in the methylation pattern of H19-DMR was also present in the peripheral blood DNA of this patient.

Each of the seven CTCF binding sites of the human H19 promoter contains 3-5 CpG dinucleotides within an $~ 50$-bp stretch that could potentially play a role in imprinting. The allele-specific methylation of this site $(22,44)$ and the correlation between the methylation status of the sixth CTCF binding site and the expression of either IGF2 or H19 in human-mouse somatic cell-hybrid clones containing a single copy of human chromosome 11 (21) suggest that this site is a key element in the imprinting control region. A novel finding in our study was the $\mathrm{C} / \mathrm{T}$ polymorphism identified by the endonuclease, HhaI, in CTCF binding site 6. It is thought that the number of functional CTCF binding sites in the DMR correlates with their insulator activity and this C/T SNP could influence the stability of the binding to the unmethylated allele in this critical imprinting control region (45). The comparison of the genotypes, CC and CT + TT, in the 95 patients with cancer and in the 157 volunteers revealed a statistical trend towards a lower frequency of the homozygous wild-type CC genotype in the cancer group. However, a larger case-control cohort is required to provide sufficient evidence to demonstrate an association between genetic polymorphisms in the DMR and susceptibility to cancer.

Collectively, these data indicate that the epigenetic heterogeneity of genomic imprinting is a stable characteristic with the potential to influence the phenotype, especially in relation to the development of cancer. This complex process can be regulated by variations in the extent of methylation, the genes that modify imprinting, the histone acetylation patterns, and the repressor proteins that bind to chromatin (46). The identification of inter-individual variability in the mechanisms responsible for establishing and/or maintaining the methylation patterns of H19-DMR, and identification of the genetic and environmental factors that influence this pattern, represent important steps in determining how imprinting and epigenetic mechanisms can modulate the risk of cancer in the general population (47). New studies are clearly required to elucidate the role of the genetic and epigenetic heterogeneity of the DMR in pathological conditions in which the imprinting of the IGF2 and H19 genes is disrupted.

\section{Acknowledgements}

This work was supported by grants from the Fundação de Amparo à Pesquisa do Estado de São Paulo (Fapesp 00/13850-2 and 00/14234-3), the Fundação para o Desenvolvimento da Unesp (Fundunesp), the Coordenação de Aperfeiçoamento de Pessoal de Nível Superior (CAPES), and the Conselho Nacional de Desenvolvimento Científico e Tecnológico (CNPq - 540689/01-7 and 305145/02-9), Brazil. We would like to thank Dr Jeremy A. Squire, University of Toronto, Canada, for reading and commenting on the work, as well as the directors and staff of the Registro Hospitalar de Câncer e Serviço de Arquivo Médico e Estatística of Amaral Carvalho Hospital in Jaú, SP, and of the A.C. Camargo Hospital in São Paulo for providing access to the clinical records of the patients studied here, Isabel Domingos Claro for her help in collecting the samples, and Érika da Costa Prando for their excellent technical assistance.

\section{References}

1. Das PM and Singal R: DNA methylation and cancer. J Clin Oncol 22: 4632-4642, 2004.

2. Esteller M: Dormant hypermethylated tumour suppressor genes: questions and answers. J Pathol 205: 172-180, 2005.

3. Issa JP: $\mathrm{CpG}$ island methylator phenotype in cancer. Nat Rev Cancer 4: 988-993, 2004

4. Cai YC, Yang GY, Nie Y, et al: Molecular alterations of p73 in human esophageal squamous cell carcinomas: loss of heterozygosity occurs frequently; loss of imprinting and elevation of p73 expression may be related to defective p53. Carcinogenesis 21: 683-689, 2000.

5. Zhang Y and Tycko B: Monoallelic expression of the human $H 19$ gene. Nat Genet 1: 40-44, 1992. 
6. Bell AC and Felsenfeld G: Methylation of a CTCF-dependent boundary controls imprinted expression of the Igf2 gene. Nature 405: 482-485, 2000.

7. Hark AT, Schoenherr CJ, Katz DJ, Ingram RS, Levorse JM and Tilghman SM: CTCF mediates methylation-sensitive enhancerblocking activity at the H19/Igf2 locus. Nature 405: 486-489, 2000.

8. Thorvaldsen JL, Mann MRW, Nwoko O, Duran KL and Bartolomei M: Analysis of sequences upstream of the endogenous $\mathrm{H} 19$ gene reveals elements both essential and dispensable for imprinting. Mol Cell Biol 22: 2450-2462, 2002.

9. Rainier S, Johnson LA, Dobry CJ, Ping AJ, Grundy PE and Feinberg AP: Relaxation of imprinted genes in human cancer. Nature 362: 747-749, 1993.

10. Ogawa O, Becroft DM, Morison IM, et al: Constitutional relaxation of insulin-like growth factor II gene imprinting associated with Wilms' tumour and gigantism. Nat Genet 5: 408-412, 1993.

11. Steenman MJ, Rainier S, Dobry CJ, Grundy P, Horon IL and Feinberg AP: Loss of imprinting of IGF2 is linked to reduced expression and abnormal methylation of $H 19$ in Wilms' tumour. Nat Genet 7: 433-439, 1994. Erratum in: Nat Genet 8: 203, 1994.

12. Moulton T, Crenshaw T, Hao Y, et al: Epigenetic lesions at the H19 locus in Wilms' tumour patients. Nat Genet 7: 440-447, 1994.

13. Kim HT, Choi BH, Niikawa N, Lee TS and Chang SI: Frequent loss of imprinting of the $H 19$ and $I G F-I I$ genes in ovarian tumors. Am J Med Genet 4: 391-395, 1998.

14. Cui H, Horon IL, Ohllsson R, Hamilton SR and Feinberg AP: Loss of imprinting in normal tissue of colorectal cancer patients with microsatellite instability. Nat Med 4: 1276-1280, 1998.

15. Kondo M, Suzuki H, Ueda R, et al: Frequent loss of imprinting of the $\mathrm{H} 19$ gene is often associated with its overexpression in human lung cancers. Oncogene 16: 1193-1198, 1995.

16. Elkin M, Shevelev A, Schulze E, et al: The expression of the imprinted H19 and IGF-2 genes in human bladder carcinoma. FEBS Lett 4: 57-61, 1995.

17. El-Naggar AK, Lai S, Tucker AS, et al: Frequent loss of imprinting at the IGF2 and H19 genes in head and neck squamous carcinoma. Oncogene 18: 7063-7069, 1999.

18. Rainho CA, Kowalski LP and Rogatto SR: Loss of imprinting and loss of heterozygosity on $11 \mathrm{p} 15.5$ in head and neck squamous cell carcinomas. Head Neck 23: 851-859, 2001.

19. Ohlsson R, Renkawitz R and Lobanenkov V: CTCF is a uniquely versatile transcription regulator linked to epigenetics and disease. Trends Genet 17: 520-527, 2001.

20. Kanduri C, Holmgren C, Pilartz M, et al: The 5' flank of mouse H19 in an unusual chromatin conformation unidirectionally blocks enhancer-promoter communication. Curr Biol 10: 449-457, 2000.

21. Takay D, Gonzales FA, Tsai YC, Thayer MJ and Jones PA: Large scale mapping of methylcytosines in CTCF-binding sites in the human H19 promoter and aberrant hypomethylation in human bladder cancer. Hum Mol Genet 10: 2619-2626, 2001

22. Frevel MA, Sowerby SJ, Petersen GB and Reeve AE: Methylation sequencing analysis refines the region of $\mathrm{H} 19$ epimutation in Wilms' tumor. J Biol Chem 274: 29331-29340, 1999.

23. Nakagawa H, Chadwick RB, Peltomaki P, Plass C, Nakamura Y and De la Chapelle A: Loss of imprinting of the insulin-like growth factor II gene occurs by biallelic methylation in a core region of H19-associated CTCF-binding sites in colorectal cancer. Proc Natl Acad Sci USA 98: 59159-59166, 2001.

24. Cui H, Cruz-Correa M, Giardiello FM, et al: Loss of IGF2 imprinting: a potential marker of colorectal cancer risk. Science 299: 1753-1755, 2003

25. Ransohoff DF: Developing molecular biomarkers for cancer. Science 299: 1679-1680, 2003.

26. World Health Organization: International Classification of Diseases for Oncology. 2nd edition. World Health Organization, Geneva, 1990.
27. American Joint Committee on Cancer: Manual for Staging of Cancer. 5th edition. J.B. Lippincott, Philadelphia, 1992.

28. Frommer M, McDonald LE, Millar DS, et al: A genomic sequencing protocol that yields a positive display of 5-methylcytosine residues in individual DNA strands. Proc Natl Acad Sci USA 89: 1827-1831, 1992.

29. Ewing B, Hillier L, Wendl MC and Green P: Base-calling of automated sequencer traces using Phred. I. Accuracy assessment. Genome Res 8: 175-185, 1998.

30. Ewing B and Green P: Base-calling of automated sequencer traces using Phred. II. Error probabilities. Genome Res 8: 186-194, 1998.

31. Gordon D, Abajian D and Green P: Consed: a graphical tool for sequence finishing. Genome Res 8: 195-202, 1998.

32. Grunau C, Schattevoy R, Mache N and Rosenthal A: MethTools - a toolbox to visualize and analyze DNA methy-lation data. Nucleic Acids Res 28: 1053-1058, 2000

33. Jinno Y, Sengoku K, Nakao M, et al: Mouse/human sequence divergence in a region with a paternal-specific methylation imprint at the human H19 locus. Hum Mol Genet 5: 1155-1161, 1996.

34. Feinberg AP: Imprinting of a genomic domain of $11 \mathrm{p} 15$ and loss of imprinting in cancer: an introduction. Cancer Res 59: 1743S-1746S, 1999.

35. Randhawa GS, Cui H, Barletta JA, et al: Loss of imprinting in disease progression in chronic myelogenous leukemia. Blood 91: 3144-3147, 1998.

36. Weksberg R, Shen DR, Fei YL, Song QL and Squire JA: Disruption of insulin-like growth factor 2 imprinting in BeckwithWiedemann syndrome. Nat Genet 5: 143-149, 1993.

37. Joyce JA, Lam WK, Catchpoole DJ, et al: Imprinting of IGF2 and H19: lack of reciprocity in sporadic Beckwith-Wiedemann syndrome. Hum Mol Genet 6: 1543-1548, 1997.

38. Sakatani T, Kaneda A, Iacobuzio-Danahue CA, et al: Loss of imprinting of Igf2 alters intestinal maturation and tumorigenesis in mice. Science 307: 1976-1978, 2005.

39. Giannoukakis N, Deal C, Paquette J, Kukuvitis A and Polychronakos C: Polymorphic functional imprinting of the human IGF2 gene among individuals, in blood cells, is associated with H19 expression. Biochem Biophys Res Commun 220: 1014-1019, 1996.

40. Sakatani T, Wei M, Katoh M, et al: Epigenetic heterogeneity at imprinted loci in normal populations. Biochem Biophys Res Commun 283: 1124-1130, 2001.

41. Sandovici I, Leppert M, Hawk PR, Suarez A, Linares Y and Sapienza C: Familial aggregation of abnormal methylation of parental alleles at the IGF2/H19 and IGF2R differentially methylated regions. Hum Mol Genet 12: 1569-1578, 2003.

42. Thilgman SM: The sins of the fathers and mothers: genomic imprinting in mammalian development. Cell 96: 185-193, 1999.

43. Pardo-Manuel de Villena F, De la Casa Esperon E and Sapienza C: Natural selection and the function of genome imprinting: beyond the silenced minority. Trends Genet 16: 573-579, 2000.

44. Vu TH, Li T, Nguyen D, Nguyen BT, Yao XM, Hu JF and Hoffman AR: Symmetric and asymmetric DNA methylation in the human IGF2-H19 imprinted region. Genomics 64: 132-143, 2000.

45. Pant V, Mariano P, Kanduri C, et al: The nucleotides responsible for the direct physical contact between the chromatin insulator protein $\mathrm{CTCF}$ and the $\mathrm{H} 19$ imprinting control region manifest parent of origin-specific long-distance insulation and methylationfree domains. Genes Dev 17: 586-590, 2003.

46. Tycko B: Epigenetic gene silencing in cancer. J Clin Invest 105: 401-407, 2000.

47. Verma M, Dunn BK, Ross S, et al: Early detection and risk assessment. Ann NY Acad Sci 983: 298-319, 2003. 